\title{
The Effect of Multiple Role Conflict (Family Work) and Work Stress on Women Nurse Performance
}

\author{
Mar'atun Sholihah ${ }^{1}$, Ratna Indrawati ${ }^{2}$ \\ UNIVERSITAS ESA UNGGUL ${ }^{1,2}$
}

\begin{abstract}
Economic growth and the increasing basic neessities for clothing, food and shelter, encourage women to play an active role in the public sector. Women contribution to economic development can be seen from women's participation in the workforce. Multiple role conflicts can be faced by women with various professions, one of them is a nurse. Hospital nurses are dominated by female workers. As a nurse who is married, they are required to always act professionally in their work and not jumble in work conflicts with family. Multiple role conflict (work-family) will be a problem if there is no right solution to overcome it, the impact is the occurrence of pressure, anxiety that makes employees lead to stress and performance. This study aims to determine the effect of multiple role conflict (work-family) and work stress on performance. The samples in this study were 132 nurses who met the inclusion criteria. The research method used a quantitative method with a Likert scale to measure research results. To test the hypothesis proposed in this study the analysis technique used is SEM (Structural Equation Model) which is operated through the lisrel program. The results of the study prove that multiple role conflict has a significant positive effect on work stress and performance. And work stress negatively affects the performance of female nurses in the hospital.
\end{abstract}

Keywords: Multiple Role Conflict (Work-Family Confict), Job Stress, Performance, Women Nurse.

\section{INTRODUCTION}

Human resources in the organization are crucial aspects determining the effectiveness of an organization. Therefore, the organization always needs to make investments by implementing the HRM function, starting from recruitment, selection to retain human resources. Along with economic development and the increasing basic nessecities for clothing, food and shelter, encouraging women to play an active role in the public sector. Women contribution to economic development can be seen from women participation in the workforce. In Indonesia, the number of active female labor forces increased from 36,871,239 in 2000 to 46,509,689 in 2012 (BPS, 2000 and 2012). This shows that in quantity, female workers are a very potential factor of labor. Women work, either working alone or as employees both are known as career women. This career woman at least undergoes two roles at once which are not easy, called as a worker and also as a housewife, mother and housewife. Multiple role conflicts can be faced by all women with various professions, one of them is a nurse. Nurses are one of the professions that are mostly dominated by women and as nurses are required to always standby 24 hours a dayin caring for, maintaning, and taking care of patients. As a nurse, they are required to always act professionally in their work in dealing with various kind patient characteristics. They are required not to jumble work conflicts with families.

Multiple role conflict (work-family) will be a problem if there is no right solution to overcome it, the impact is the occurrence of pressure, anxiety that makes employees lead to stress. This is consistent with the opinion (Frone, 2000 in Roboth, 2015) which says that dual role conflict (work-family) is very strongly associated with depression and anxiety suffered by women compared to men and is also related to the traditional role of women who can be avoided, namely responsibility in managing the houswife and growing children.

The Word Health Organization (WHO) (2011) argued that several countries in Southeast Asia including Indonesia, the fact that nurses who worked in hospitals got an increasing in workload and got decreasing mount of nurses. The Word Health Organization (WHO) states stress is an epidemic that spreads throughout the world. PBB report dubbed work stress as a 20th century disease. The American Institute of Stress stated that stress-related diseases have caused economic losses in the United States of more than \$ 100 billion per year. As many as $90 \%$ of health services in hospitals are nursing services from several studies stated that work stress is a common thing for nurses. If the nurse has a high stress level it will reduce the quality of the nurse works besides that the profession as a nurse. Providing a high contribution to the incidence of work stress based on this work by $6.2 \%$. Research in the United States also mentions that $65 \%$ of career women have a more gloomy future. They experience many conflicts in their work due to perceived stress. Women who become housewife and career women tend to bring them to work-family conflict. Although men can 


\section{International Advanced Research Journal in Science, Engineering and Technology}

Vol. 7, Issue 10, October 2020

\section{DOI 10.17148/IARJSET.2020.71010}

also experience work family conflict but women remain the main focus, because it is related to their main duties as mothers and housewife. Women not only act as housewives but have other roles outside the home, called as career women. Indonesian nurses who work in four provinces as many as $50.9 \%$ experience work stress, often feel dizzy, tired of no rest because the burden is too high and time consuming, low salaries without salary incentives. Nurses working in private hospitals with salaries are better at experiencing greater work stress than nurses working in government hospitals with lower incomes (PPNI in Prismayanti, 2010).

Nurses experience a level of work-family conflict can also experience a decline in performance because they will be more controlled by their work because nurses can not responsible with their family, because it reduces their quality of family life, but stress has positive and negative impact. The positive impact of stress at a low level in moderate level is functional as a role encourage to increas employee performance, while at a high level of stress at a high level decrease in drastic employee performance (Robbins, 2010).

The decreasing level of performance appropiate with the employee's work in a role can be experienced if someone often fails to fulfill that role because the employee does not interfere with her family. Employees experience a high level of work-family conflict report a decreasing in performance woker because they feel that they are more controlled by their work the effect to employees can not rensponsiblewith their family, because they decrease the quality of their family's life.

The difference between the previous and Harleys (2015) research where research took the pilot profession as a sample with an online system in answering questionnaires sent directly using e-mail would be different when the research was done by direct observation, then research conducted by Wayne (2004) research was carried out by various kinds a profession carried out by women who make money using family welfare data that has been used for years by random systems for the family. And the people who were the sample of the study answered questionnaires using telephone services, of course these results will be different from the research that will be conducted in the current study, where research uses data with the same profession, nurses who entered the research inclusion criteria and answered questionnaires directly.

\section{LITERATURE REVIEW}

\section{Multiple Role Conflict (Family-Work)}

Robbins (2015) argues that conflict is a process that begins when one side has a perception that the other side gave negative affect, or does not negative affect, something that is the concern or interests of the first side. (Greenhouse, et al. 1995 in Azzah 2009) Multiple role conflict is a conflict appear from pressure from work and family.

Natemeyer et al. (1996) in Anafara (2011) defines work-family conflict as a form of conflict where the general demands, time and tension that come from work interfere with employee responsibilities towards the family. Role conflict is bi-directional and multidimensional, where each part or dimension influences each other (Greenhause and Beutell, 1985). The nature of bi-directional dual role conflict consists of two interrelated aspects, called; (i). Work-Family Conflict is a conflict that arises due to job responsibilities that interfere with family responsibilities. Work-Family Conflict usually occurs when a person tries to fulfill the demands of the role in work and business is influenced by the ability of the person concerned to meet the demands of the family or vice versa, where the fulfillment of the demands of the role in the family is influenced by the person's ability to fulfill demands and pressures stemming from excessive workloads and times such as work that must be completed in a hurry and deadline while family demands relate to the time needed to handle tasks in the household; (ii) Family - Work Conflict is a conflict that arises because family responsibilities interfere with work responsibilities. The family can be seen in the narrow sense as a nuclear family which is the smallest social group of the community formed based on marriage consisting of parents and children who are still dependent and living in one house (Subhan, 2004). The family is the unity of a number of people who interact and communicate in order to carry out their social roles as husbands, wives and children, brothers and sisters. This role is determined by society, but the role in the family is reinforced by these feelings.

Multidimensional role conflict arises from each direction where both the Work-Family Conflict and FamilyWork Conflict have three dimensions, called; (i) time-based conflict the time needed to carry out one of the demands (family or work) can reduce the time to carry out other demands (work or family); (ii) strain-based conflict occurs pressure from one of the roles influencing the performance of other roles; (iii) Behavior-based conflict relates to a discrepancy between behavioral patterns and those desired by both parts (work or family). Further explained that role conflict has two forms, there are family work conflict and work family conflict.

\section{Work stress}

Lovibond (1995) defines stress as a response that arises from stressful events in an individual life and explains when individual stress tends to become more irritable, difficult to calm down, and become impatient in dealing with various situations. Robin (2015) stress is a dynamic condition in which an individual is faced with an opportunity, demand, or resource related to what the individual desires and whose results are considered uncertain and important. Stress is more often associated with demands (demands) and resources (resources). Demands are the responsibility, 


\section{International Advanced Research Journal in Science, Engineering and Technology}

Vol. 7, Issue 10, October 2020

\section{DOI 10.17148/IARJSET.2020.71010}

pressure, obligation, and even uncertainty faced by individuals at work. Resources are things (or objects) that are in the sense of work stress is the response of an individual to workplace stressors. Physiological stress that is not beneficial such as extreme cold and heat, difficulties and distress, poverty, damage, pain, infection, and severe poisoning (Berzwinsky, 1992 in Ahari, 2013).

Robbins (2010) stress is a dynamic condition in which an individual is confronted with an opportunity, constraint, or demand that is associated with the very desired and the results are perceived as uncertain and important. Stress as a reaction to an organism, it can be a physiological, psychological, or behavior reaction.

Job stress as an interaction of various factors, there are stress in work as an external factor, character and perception of employees as internal factors. Conditions that tend to generate stress are called stressors. There are 2 categories of stressors, called by on the job and off the job, namely; (i) working conditions on the job that cause work stress are stress caused by problems that occur in the company, called excessive workload, pressure or time pressure, poor quality supervisors, insecure political climate, inadequate feedback on the implementation of work. Authority is insufficient to carry out responsibilities, lack clarity of roles, conflicts between personal and group and frustrated; (ii) causes of off-the-job problems, namely financial worries, problems related to children, physical problems, marital problems such as divorce, changes in homes, and other personal problems. Stress on the job is more dominant than stress of the job because most of the time is spent at work.

Robbins (2010) categorizes stress types into two, there is: 1). Eustress, which is the result of a response to stress that, is healthy, positive, and constructive (constructive). This includes the welfare of individuals and also organizations associated with growth, flexibility, adaptability, and high levels of performance; 2). Distress, which is the result of a response to stress that, is unhealthy, negative, and destructive. These include the consequences of individuals and also organizations, such as cordovascular disease and high absenteeism rates associated with illness, decline and death.

\section{Performance}

Motowidlo and Van Scotter (1994) reveal that work performance based on to the results obtained from subtantite tasks that differentiate one's work from other work and include more technical aspects of performance. Work performance contributes to the organization by changing raw materials as part of the steps to produce organizational products. Donations provided by work performance can also provide important services and perform maintenance functions such as, filling in the supply of raw materials, distributing service products and producing planning, coordination and supervision. Performance is a level of role of organizational members in achieving organizational goals, the role in question is the implementation of an action to carry out and complete a given task (Simamora, 2009). Hamzah and Lamatenggo (2014) define performance as a person's behavior that produces certain work results after fulfilling a number of requirements. Whereas Abdullah (2005) stated that performance is the result or success rate of a person throughout a certain period in carrying out a task compared to various possibilities, such as work standards, targets or articles or predetermined criteria and mutually agreed upon.

Understanding Robbins performance (2010) performance is the result of evaluating the work done by employees compared to predetermined criteria. Understanding Moeheriono's performance (2012) is "performance or performance is a description of the level of achievement of the implementation of an activity program or policy in realizing the goals, objectives, vision and mission of the organization as outlined in strategic or organizational planning.

\section{HYPOTHESIS}

The hospital is an institution that provides health services to the community with the aim of healing illnesses and avoiding death or disability. In carrying out its function the hospital must also control or minimize the risks both clinical and nonclinical that may occur during the process of health care takes place so that a safe service for patients is carried out. Therefore, patient safety is a priority in all forms of hospital activities. PERMEKES NO. 562014 Type C Hospital Service Standards, article 44 paragraph 1 (one) and where it is stated that the number of nursing staff as based on to in article 43 paragraph (1) letter $\mathrm{c}$ is calculated in the ratio of 2 (two) nurses for 3 (three) bed. Article 44 paragraph 2 (two) states that the qualifications and competencies of nursing staff as referred to in paragraph 1 (one) are adjusted to the needs of hospital services.

This dual role conflict (work-family) will be a problem if there is no right solution to overcome it, the impact is the occurrence of pressure, anxiety that makes employees lead to stress. This is in accordance with the opinion (Frone, 2000 in Roboth, 2015) which states that multiple role conflict is strongly related to depression and anxiety suffered by women compared to men and also relates to the traditional role of women which until now cannot be avoided, called by responsibility responsible for managing the housewife and growing children.

Multiple role conflicts can be faced by all women with various professions, one of them is a nurse. Nurses are one of the professions that are mostly dominated by women and as nurses are required to always be 24 hours a day in caring for, caring for, and taking care of patients. As a nurse, they are required to always act professionally in their work in dealing with various patient characteristics. They are required not to mix work conflicts with their families, while as a wife and a mother they are also faced with requests from the family to continue to carry out their duties as a wife and mother for 


\section{International Advanced Research Journal in Science, Engineering and Technology}

Vol. 7, Issue 10, October 2020

\section{DOI 10.17148/IARJSET.2020.71010}

their

children.

Job-family conflict tends to lead to work stress because when work matters interfere with family life, pressure often occurs in individuals to reduce time spent in work and provide more time for the family (Judge, 1994 in Roboth, 2015). Of the three research variables above and their effects on employee performance have been carried out by previous research, the authors try to do similar research at H.M. Hospital. Judono Bangka Belitung.

\section{Effect of Multiple Role Conflict (work-family) on Stress.}

Employees, especially mothers working with small children, multiple role conflict (work-family) will be a problem if there is no right solution to overcome it, the impact is the occurrence of pressure, anxiety that makes employees lead to stress. This is in accordance with the opinion (Frone, 2000 in Roboth, 2015) which states that multiple role conflict is strongly related to depression and anxiety suffered by women compared to men and also relates to the traditional role of women which until now cannot be avoided, which is responsibility responsible for managing the housewife and growing children.

Work-family conflicts tend to lead to work stress because when work matters interfere with family life, pressure often occurs on individuals to reduce time spent in work and provide more time for families. Pressure to develop these two roles can cause stress. Job-family conflict is one form of inter-role conflict where pressure from work disrupts the implementation of family roles. Thomas and Ganster (1995) state that $38 \%$ of men and $43 \%$ of women who are married and have jobs and children are reported to experience work-family conflicts.

\section{Effect of Work Stress on Performance}

Female nurses are married and had children had heavier roles and responsibilities than single female nurses. The double role was also experienced by the female nurse because in addition to play a role in the family, the female nurse also played a role in her career. Nurses experience a level of work-family conflict can experience a decline in performance because they will be more controlled by their work and because nurses can not fulfill their family responsibilities, because it reduces the quality of family life but stress has a positive and negative impact. The positive impact of stress at a low level to a moderate level is functional in the sense that it acts as a driver to increase employee performance, while at a high level of stress at a high level is a decrease in drastic employee performance (Robbins, 2010).

\section{Effect of Multiple Role Conflict (Work-Family Conflict) on Performance}

Work conflict can affect the performance of employees in a company. Conflict is unhealthy competition based on emotional ambitions and attitudes in gaining victory can lead to tension, confrontation, contention, stress and frustration if their problems cannot be resolved. This will certainly harm the company in the form of a decrease in performance due to stress and conflict in the work environment. This is important to be known by the company in order to take preventive measures. Likewise, the conflict over the multiple role of women workers consists of work-family conflicts. Job-family conflict is negative related to female employee performance. Employees experience a high level of work-family conflict reported a decline in performance because they feel that they are more controlled by their work resulting in employees not being able to fulfill their family responsibilities, because they reduce the quality of their family's life. Such explanations can be similarly given to family-work conflict relations with employee performance (Frone, (1994) in Roboth, (2015).

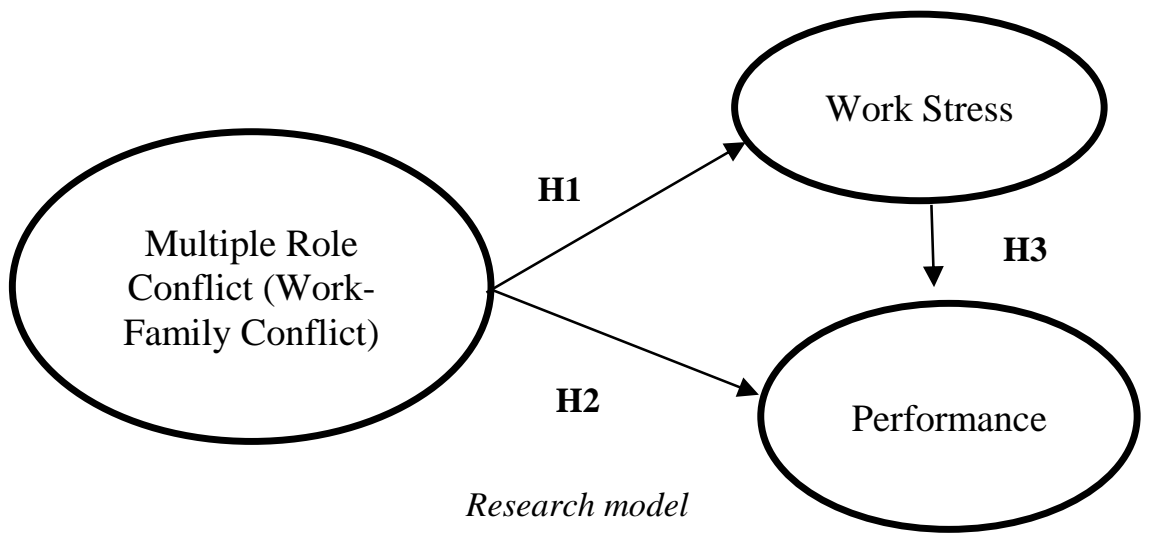

\section{RESEARCH METHODS}

This study was conducted on all female nurses at the Bangka Belitung Regional General Hospital. The aspect studied was Multiple Role Conflict (Family Work, Job Stress, and Performance. The study was conducted in March 2018 with the survey method. The design in this study is descriptive, with a Cross Sectional approach. Data collection was carried 


\section{International Advanced Research Journal in Science, Engineering and Technology}

Vol. 7, Issue 10, October 2020

\section{DOI 10.17148/IARJSET.2020.71010}

out by distributing questionnaires to all nurses who entered inclusion in the study. Data analysis method in this study uses SEM statistics; the data is processed using statistical software. Researchers determine the minimum sample size in this study using according to Sugiyono (2010) saturated sampling is a sample determination technique if all members of the population are used as samples. Another term saturated sample is a census, where all members of the population are sampled; this study uses 132 respondents who are all nurses who meet the inclusion criteria in the study. The collected data is then measured by measuring the variables in this study using a Likert scale which is adjusted to each tool used. The results of the analysis are then interpreted and the final step is concluded and given advice.

\section{Measurement}

Pre-test is done by distributing 30 respondents; the results of this study use confirmatory factor analysis, by validity testing by looking at the Kaiser-Meyer-Olkin measure of sampling (KMO) and measures of sampling adequacy (MSA). In this test the value obtained must be greater than 0.5 , which means that factor analysis is appropriate or appropriate for use, and can be further processed (Malhotra, 2007). Measurment of Multiple Role Conflict variables using a questionnaire consist of five questions. Work Stress Variables twentyone questions and variable Performance Sixteen Questions. The scale obtained in this measurement with Kaiser-Meyer-Olkin measure of sampling (KMO) and measures of sampling adequacy (MSA) obtained KMO> 0.5 and MSA $>0.5$

This survey consisted of fourty-two items which used a Likert Scale. The results of this measurement obtained 1 invalid question which had two component matrixes when entered in the data processing so that it was not included in the research questionnaire and Cronbach alpha coefficient $>0$ each, 6 . Reliability test with Alpha Cronbach value $>0.6$ which means reliable it can be said that indicators of transformational leadership, organizational commitment, job satisfaction and patient safety culture they can be said to be trusted as a data collection tool in research.

\section{RESULT AND DISCUSION}

Chi Square value 175.97, RMSEA = 0.045, ECVI model (2.13) compared with ECVI saturated models (2.90) and ECVI Independent models (43.52). AIC model (279.48) is compared with AIC saturated (380.00) and AIC independence (5700.67). The CAIC model (489.15) is far from the CAIC saturated (1117.73) and also further from CAIC independence (5774.45), so the smaller value shows a good match. Normed fit index (NFI) $=0.97$ (above 0.90) indicates goodfit. Critical N $(\mathrm{CN})=132.98<200$, the model does not represent the sample size of poor fit data. Goodness of Fit Index $(\mathrm{GFI})=0.88$ (below 0.90 ) indicates marginal fit. Furthermore, the study produced a T-Value diagram.

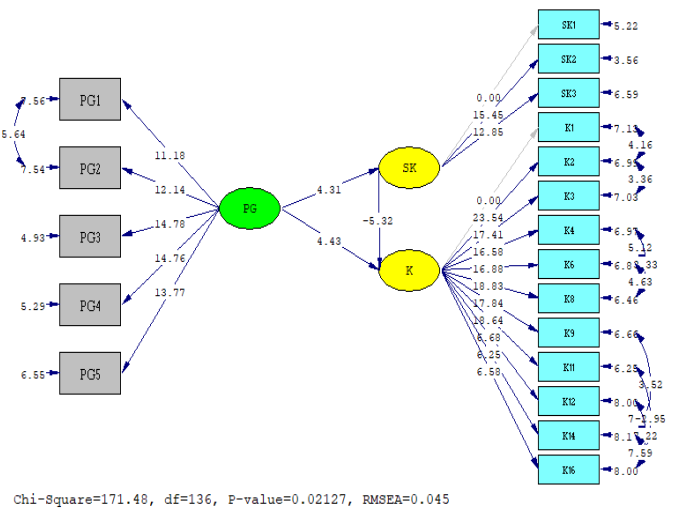

\begin{tabular}{|c|l|c|l|}
\hline Hypotesis & Hypothesis statement & T-Value & Information \\
\hline H 1 & $\begin{array}{l}\text { Effect of Multiple } \\
\text { Role Conflict (work- } \\
\text { family) on Stress. }\end{array}$ & 4.31 & $\begin{array}{l}\text { There are } \\
\text { Influences }\end{array}$ \\
\hline H2 & $\begin{array}{l}\text { Effect of Work Stress } \\
\text { on Performance }\end{array}$ & -5.32 & $\begin{array}{l}\text { No } \\
\text { Influences }\end{array}$ \\
\hline H3 & $\begin{array}{l}\text { Effect of Multiple } \\
\text { Role Conflict (Work- } \\
\text { Family Conflict) on } \\
\text { Performance }\end{array}$ & 4.43 & $\begin{array}{l}\text { There are } \\
\text { Influences }\end{array}$ \\
\hline
\end{tabular}

In the first test results (H1), it was found that the results of the analysis support the $\mathrm{H} 1$ hypothesis, namely that there is an influence between the multiple roles with work stress by 4.31. This shows that work stress is influenced by the multiple roles of nurses. The higher the dual role, the more work stress will increase. These results indicate that there is a positive influence between dual role conflict and work stress, meaning that the higher the level of multiple role conflict, the higher the level of work stress. This is consistent with research from Almasitoh (2011) which states that there is a relationship between multiple role conflict and social support for work stress on nurses where someone who has a high multiple role conflict and low social support has a high level of work stress. The theory revealed by Netemayer et.al. (1996) workfamily role conflict occurs when demands from the workplace, in the form of a number of times used to do work tasks and stress or pressure causes the work system to interfere with the completion of family tasks. Family-work conflicts occur when family demands, in the form of a number of times spent working on family tasks and stress or pressure cause a family system to interfere with the completion of work tasks (Frone, et.al. (1992) Netemeyer, et.al. (1996). According to Luthans (2001), a person will experience role conflict if he has two or more pressures that occur simultaneously and if he tries to obey one of them, then he will experience difficulties. A woman who works in addition to taking up a lot of time also takes up a lot of energy because she must share the energy she has to work and also take care of the family. 


\section{International Advanced Research Journal in Science, Engineering and Technology}

Vol. 7, Issue 10, October 2020

\section{DOI 10.17148/IARJSET.2020.71010}

Conflicts that occur between work and family make nurses unable to balance their time and energy, causing the nurse to experience fatigue or overload which then triggers work stress (Ruswanti E, 2013). Nurses work with a shift system which is certainly more energy consuming so that nurses are more susceptible to higher work fatigue because working with the shift system requires workers to work in the morning, afternoon and night continuously. This is consistent with Nature's research which states that there is a significant relationship between work shifts and work fatigue, where the highest work fatigue is experienced by workers who run night shifts (Kimberly, 2011).

The second test result (H2), found that the results of the analysis did not support the hypothesis $\mathrm{H} 2$, that there was no effect between works stresses of -5.32 on performances rejected. These results are consistent with the research conducted by Adawiyah (2015), which shows that job stress has no direct effect on employee performance. Nurses are able to manage work stress well, including from organizations that have created performance and comfortable colleagues. So that the more comfortable the workplace increases employee performance. So that even though the work stress that is charged high will not affect the performance of employees this is characterized by employees working passion and able to achieve the desired performance of the company, and responsible for working to develop potential performance, a conducive work environment, interaction between nurses and superiors is good enough, burden the work they feel is not too heavy, is service and routine and they usually do it as a nurse profession so as to achieve good performance nurses can still do a good job. From the start nurses are able to put themselves in and carry out their functions well where they work and which room they will get. And this result is in accordance with Sanjaya's (2012) research, even though employees experience work stress, employee performance is still high. Price (2003) in Jane Y. Roboth (2015) said that workplace stress also positively correlates with employee performance; work stress can create competitive advantage for companies with good management. Job stress also has other positive effects such as with time constraints can be more efficient and effective. Job stress has a positive or negative impact. According to Gitosudarmo and Suditta, (1997), the positive impact of work stress at a low level to moderate level is functional in the sense of acting as a driver to increase employee performance while the negative impact of work stress at a high level is a drastic reduction in employee performance. Robbins (2006) states that work stress levels that are able to be controlled can make employees do their work better, because it makes them able to increase work intensity, alertness, and creative ability, but excessive stress levels of work make their performance will decrease. Here Robbins (2006) also divides that stress is divided into two types, that are eustress and distress stress levels that can be controlled to make employees do their work better, because it makes them able to increase work intensity, alertness, and creative abilities, but excessive stress levels make performance they will experience a decline. According to Price (in Indriyani, 2009) said that workplace stress is also positively related to employee performance. Stress can create competitive advantage for companies with good management. Job stress depends on individuals facing a problem, there are individuals who, when facing an excessive workload, are challenged to be more active and more diligent in achieving their targets. Then individuals who do not feel job stress but are even more eager to work to meet the target.

In the first test results (H3), it was found that the results of the analysis supported the H3 hypothesis, namely that there was an influence between the dual roles of 4.43 on performance. This hypothesis agrees with the research conducted by Netemeyer et.al. (2005) work-family conflict explains the occurrence of collisions between homework responsibilities. This means that multiple role conflicts experienced by career women can cause obstacles in work. As stated (Orenstein in Puji, 2008) that is a multiple role can make it difficult for women to achieve success in the fields of work, family and interpersonal relationships at once. If you do not want to be like that, it is recommended that the woman is not principled as a super woman who is capable of doing everything herself. The inability of career women to resolve multiple role conflicts can cause them to display negative work attitudes such as lack of motivation in work, lack of concentration, due to family matters so that it will affect performance. These results are consistent with the research that has been done by Fridawati (2014) stating that multiple role conflict (work-family) has an influence on employee performance. The influence is between multiple role conflict (work-family) and performance. Today many women work outside the home to meet the needs of both themselves and their families. For women who are married and had a family, working outside the home means they have an additional role, not only as workers but also as housewives. For women working and having a family, they will have a different performance than women who work but do not have a family. This is because for workwife, they have to undergo two different roles, namely being a woman worker and as a housewife, and for working mothers unable to live it well, they will experience multiple role conflicts. The low level of performance associated with the employee's work in a role can be experienced if someone often fails to fulfill that role because the employee does not interfere with his family's work. Employees who experience high levels of work-family conflict report a decline in performance because they feel more controlled by their work which results in employees not being able to fulfill their family responsibilities, or in other words reducing the quality of family life. This is as stated by Frone (1994) in Roboth (2015). 


\section{International Advanced Research Journal in Science, Engineering and Technology}

Vol. 7, Issue 10, October 2020

\section{DOI 10.17148/IARJSET.2020.71010}

\section{CONCLUSION}

The conclusion of this study is that there is a multiple role conflict effect (work-family) on the stress of female nurse work, the higher the multiple role conflict (family work) female nurses will increase the stress of the nurse's work. This means that nurses cannot undergo their roles as career women and also a wife and mother so that it affects the work stress of a nurse. Many things can trigger multiple role conflicts (work-family) that cause stress work in the hospital, one of which is less effective communication and less efficient use of work time so that the reduced time for nurses to get together with their families can be caused by limited medical device, work environment, and also conflict with colleagues. But in this study shows there is no effect of stress on the work of female nurses with performance, meaning that nurses do not experience high stress in the hospital and do not interfere with the performance as a nurse. This means that nurses have been able to adjust quickly whenever there is a change in work environment conditions that often experience rolling the room for nurses and also the head of the room and new associates. A good work environment, conducted hospital conditions, and superior human resources cause low levels of stress at the hospital. This is corroborated by the theory put forward by Robbin (2010) which states that not all work stress has a negative effect, where stress has a positive effect on performance. Workplace stress can also create competitive advantage for companies with good management. Stress also has other positive impacts, such as the time limit can be more efficient and effective. Job stress has a positive and negative impact. The positive impact of work stress at a low level to moderate level is functional in the sense of acting as an increase in employee performance while the negative impact of work stress at a high level is a drastic reduction in employee performance. In the results of subsequent studies there is an influence between multiple roles (work-family) and performance. This means that the higher the multiple roles (Family-Work) a nurse will affect his performance in the hospital. The inability of a career woman to resolve multiple role conflicts that occur in her can cause them to display negative work attitudes such as lack of motivation at work, difficulty cooperating with peers, easily carried away by emotions, lack of concentration due to family affairs so that it will affect performance.

\section{Research Limitations}

Research conducted by researchers today has some limitations that can be a consideration for subsequent studies. This study has a limited number of samples so that the samples taken are saturated samples. This study uses a questionnaire as a measurement tool because of the need to save time and energy. However, this questionnaire has limitations such as answers that are still biased in filling out questionnaire questions, there is a possibility that the respondents did not fill it seriously or only conditions based on ideal conditions expected and not the actual conditions that are happening, because the process of filling out the questionnaire was not done with direct interviews but only through assistance with the FGD (Focus Group Discussion) system with a number of 6-10 people at the time of shifting work shifts. This of course can cause the measurement used is not able to describe the variables significantly.

\section{Suggestion}

Based on the explanation and the things above can be suggested some suggestions that are expected to be able to reduce the level of conflict of dual roles experienced by women as workers and a wife and mother, through the arrangement of good working hours so that there is no excess work hours and cause an overload of a nurse , work evaluation, training, effective communication management, training in accordance with the ability where they will be placed in the room so that it can reduce the level of dual role conflict (work-family) and work stress that will be experienced. Nurses are able to use time more efficiently and use the remaining time to be able to gather with family. Research is still very limited because it only examines limited roles (work-family) and performance. To develop research, it is suggested that future research can examine other variables such as motivation, leadership style, loyalty, and many more that can be examined more deeply. Subsequent research is also expected to be able to add indicators to be studied so as to get better results, in addition to questionnaire indicators, in-depth direct interviews, and direct observation to see the efficiency of the work carried out can also be done to get more in-depth data and results.

In a hospital health industry, nurses are an important component in providing services and are an asset for hospitals as a determinant of whether or not health services are provided given that nurses are one of the largest components of human resources and make direct contact with patients. There for it is very important that hospitals create conditions and conditions so that nurses will feel fast and improve performance.

\section{Daftar pustaka}

[1]. Almasitoh, Ummu Hany. "Stres Kerja ditinjau dari Konflik Peran Ganda dan Dukungan Sosial pada Perawat” . Jurnal Psikologi Islam, Vol.8 No.1 tahun 2011

[2]. Badan Pusat Statistik (BPS) diakses dari http://www.bps.go.id/,

[3]. Fridawati Raslin Bangun, 2014. Pengaruh Konflik Peran Ganda Dan DukunganSosialTerhadapStres Kerja Pada Tenaga Kerja Wanita Pt Karwikarya 


\section{International Advanced Research Journal in Science, Engineering and Technology}

Vol. 7, Issue 10, October 2020

\section{DOI 10.17148/IARJSET.2020.71010}

[4]. Wisman Graha Tanjung pinang Provinsi Kepulauan Riau Tahun 2013, Tesis.Fakultas Ilmu Kesehatan Masyarakat Universitas Sumatera Utara

[5]. Frone, M. R., Russell, M.,\& Barnes, G. M. (1996). Work-family conflict, gender, and health related outcomes: A study of employed parents in two community samples. Journal of Occupational Health Psychology, I, 57-69.

[6]. Frone, M. R., Russell,M.,\& Cooper, M. L. (1997). Relation of work-family conflict to health outcomes: A four-year longitudinal study of employed parents. Journal of Occupational and Organizational Psy-chology, 70, 325-335.

[7]. Gitosudarmo, Indriyo dan Sudita, I Nyoman. 1997, Perilaku Keorganisasian, Yogyakarta : BPFE.

[8]. Greenhaus, J.H., \& Beutell, N.J. (1985). Source of Conflict Between Work and Family Roles. The Academy of Management Review, Vol. 10, No.1 (Jan., 1985), pp. 76-88

[9]. Indriyani, Azazah.(2009)“ Pengaruh Konflik Peran Ganda dan Stress Kerja terhadap Kinerja Perawat Rumah Sakit (studi kasus pada RS.Roemani)". Tesis Magister Manajemen Program PascaSarjana Universitas Diponegoro Semarang.

[10]. Irwanto, (1991). Psikologi Umum. Jakarta: PT. Gramedia Pustaka Utama

[11]. Kartono \& Gulo. (2000). Kamus Psikologi. Bandung : Penerbit Pionir Jaya

[12]. Kimberly FebrinaKodrat. Pengaruh Shift Kerja terhadap Kelelahan Pekerja Pabrik Kelapa Sawit di PT.X Labuhan Batu. J Tek Ind. 2011;12(2):110- 7.

[13]. Lovibond P.F. \&Lovibond, S.H. (1995). The structure of negative emotional states: Comparison of the Depression Anxiety Stress Scales (DASS) with the Beck Depression and Anxiety Inventories. Behaviour Research and Therapy, 33, 335-343.

[14]. Malhotra. 2007. Marketing Research An Applied Orientation.International Edition: Pearson

[15]. Netemeyer RG, Boles JS, McMurrian R (1996) Development and validation of work- family conflict and family- work conflict scales. Journal Appl Psychol 81:400-410

[16]. Netemeyer, Richard, Maxham III. James, Pullig, Chris. (2005). Conflicts in the Work-Family Interface: Links to Job Stress, Customer Service Employee Performance, and Customer Purchase Intent. Journal of Marketing; vol. 69 , Issue 2

[17]. Prismayanti, \& Faiqoh I. 2010. Hubungan Shift Kerja Dengan Stres Kerja Pada Perawat Diruang Rawat Inap Rumah Sakit Umum Daerah Dr. Soegiri Lamongan. Surabaya : 2010

[18]. Robbins, (2010), Perilaku Organisasi. Jilid 2 ( Edisi Bahasa Indonesia).

[19]. Roboth, Jane Y. (2015). Analisis Work Family Conlict, Stress Kerja dan Kinerja Wanita Berperan Ganda Pada Yayasan Compassion East Indonesia. Jurnal Riset Bisnis dan Manajemen Vol.3, No.1.renhallindo ; Jakarta

[20]. Robiyatul Adawiyah dan Siswanto (2015). stress kerja, pengaruhnya pada kinerja karyawan dengah kepuasan kerja sebagai variable mediasi. Fakultas ekonomi, Universitas Negeri Islam. Malang

[21]. Ruswanti E. Konflik antara Pekerjaan dan Keluarga, Stres Kerja terhadap Kinerja Perawat Wanita pada Rumah Sakit Bethesda. Yogyakarta. Forum Ilm. 2013;10(1).

[22]. Sanjaya. 2012. Peran Moderasi Kecerdasan Emosi pada Stres Kerja Marketing dan Collectiondi PT SummitOto Finance Kudus. Fakultas Ekonomi, Universitas Negeri Semarang, Semarang, Indonesia

[23]. Van Scotter, J. R., Motowidlo, S. J., \& Cross T. C. (1994). Effects of task performance and contextual performance on systemic rewards. Journal of Applied Psychology, 85(4), 526-535.

[24]. World Health Organization. The World Medicine Situation 2011 3ed. Rational Use of Medicine. Geneva, 2011.

[25]. Yavas, U\& Babakus, E. Attitidional and Behavioral Consequences of Work-Family Conflict and Family-Work Conflict : Does Gender Matter?” International Journal of Service Industry Management. Vol 19. No.1. 2008

Researcher:

1. Mar'atun Sholihah. in Assosiation Magister Management Esa Unggul University of Jakarta Indonesia

2. Dr. dr. Ratna Indrawati L.M.Kes is assigned to the faculty Economic Business of Higher Education Esa Unggul

University of Jakarta

Indonesia. 